\title{
Large-scale afforestation for ecosystem service provisioning: learning from the past to improve the future
}

\author{
Ignacio Pérez-Silos $(\mathbb{D} \cdot$ José Manuel Álvarez-Martínez $(\mathbb{D} \cdot$ José Barquín $(\mathbb{C}$
}

Received: 17 February 2021 / Accepted: 10 July 2021 / Published online: 23 July 2021

(C) The Author(s) 2021, corrected publication 2022

\begin{abstract}
Context Afforestation is one of the major drivers of land cover change in the world. In spite of its multiple applications, forest generation has been fostered during the last century to achieve few specific objectives such as timber production or catchment erosion protection. However, new afforestation programs are required to meet multiple objectives such as carbon sequestration, reducing environmental risks and enhance biodiversity conservation to reach sustainability.

Objectives Assessing the general efficiency of past large-scale afforestation programs on the provision of ecosystem services (ES) and other socio-ecological attributes. We also determined whether this efficiency depended on the type of ecosystem used for comparison.
\end{abstract}

Supplementary Information The online version contains supplementary material available at https://doi.org/10.1007/ s10980-021-01306-7.

I. Pérez-Silos $(\bowtie)$ · J. M. Álvarez-Martínez · J. Barquín Environmental Hydraulics Institute 'IH Cantabria', University of Cantabria, PCTCAN. C/Isabel Torres 15, 39011 Santander, Spain

e-mail: ignacio.perez@unican.es

J. M. Álvarez-Martínez

e-mail: jm.alvarez@unican.es

J. Barquín

e-mail: jose.barquin@unican.es
Methods We carried out a semi-quantitative metaanalysis from 75 studies analyzing the effects of 128 afforestation actions developed in one of the EU countries with larger areas of afforested land during the twentieth century.

Results Spanish afforestation policy improved timber provision and carbon sequestration. However, our results show that afforestation programs did not enhance regulating ES when compared to natural land plots, but only when compared to highly degraded areas prior to restoration actions.

Conclusions Large-scale afforestations have difficulties in assuring the provisioning of regulating ES and the conservation of biodiversity when only productivity criteria are prioritized. Our results suggest the need for an afforestation agenda that embraces more comprehensive landscape management approaches that allow reducing undesired ES tradeoffs while getting multiple objectives from different ecosystems.

Keywords Afforestation - Ecological succession . Ecosystem services · Forest transition - Green infrastructure networks - Multifunctional landscapes · Territory management 


\section{Introduction}

Forests cover approximately 42 million $\mathrm{km}^{2}$ on Earth, which represents one-third of the world's land area (Bonan 2008). They play a critical role in the regulation of climate and hydrological cycles, preservation of biodiversity and soil resources and provision of food, medicines or recreational values. A continuous forest cover loss during the last millennia (Pongratz et al. 2008) has compromised local to global processes involved in providing multiple ecological, social and economic services to human societies (Bongaarts 2007). Nevertheless, despite deforestation is still prevalent in some areas, according to Song et al. (2018) a forest transition could be beginning on Earth (i.e. when a region moves from losing to gain net forest cover; sensu Rudel et al. 2005). First forest transitions started during the last centuries in many countries of the northern hemisphere (e.g., Álvarez-Martínez et al. 2014). These transitions have been mainly driven by spontaneous revegetation, but also by local afforestation programs as societies undergo economic development, industrialization and urbanization (Mather 1992; Rudel et al. 2005). Nowadays, the utility of forests for counteracting the effects of droughts, floods, land degradation and, specially, climate change (Doelman et al. 2020), as well as global economic dynamics, is being reflected in the interest of other countries and supranational entities (e.g. FAO or WWF) in actively increasing forest cover (Rudel et al. 2020). Thus, new forest transitions usually imply more large-scale afforestation and faster changes in forest cover (Meyfroidt and Lambin 2011). However, the urgency to plant trees does not necessarily guarantee long-term environmental and societal benefits (Chazdon and Brancalion 2019). Tree cover can take many forms, with completely different effects on ES supply and biodiversity (Lamb 2014; Veldman et al. 2015).

Despite the wide range of benefits potentially provided by forests, afforestation has been traditionally focused on achieving only few of them. Most of the afforestation programs developed during the last century have the explicit target of timber production, replacing previously-cleared natural forests (Lamb 2014) as well as reducing the pressure over natural remaining stands (Sedjo 1999). However, these practices usually incorporate fast growing species in monocultures, which generates undesired effects and trade-offs between timber production and other regulating ES (Brockerhoff et al. 2013). These tradeoffs have favored wood production at the expense of native biodiversity, hydrological regulation or socioeconomic status of local communities (Lamb et al. 2005; van Dijk and Keenan 2007; Gerber 2011). More recently, the use of monocultures to mitigate climate change has also created other negative effects such as impoverishing biodiversity, especially when afforestation is aimed solely at carbon sequestration (Grainger et al. 2009). Complementarily, there are growing evidences that natural forests provide multiple benefits not delivered by tree plantations (Alexander et al. 2011), which has led to a change in attitude during the last decades.

Nowadays, a growing number of national restoration and rehabilitation programs aim at restoring biodiversity while enhancing ES provisioning rather than simply maximizing productivity or carbon sequestration (Brockerhoff et al. 2013; Chazdon et al. 2016; Waring et al. 2020). However, this poses a huge challenge on the forestry industry as methods developed to establish industrial timber plantations continue to be chosen simply because the species and methodologies are wellknown (Lamb 2018). As a consequence, some of the most ambitious strategies for large-scale afforestation have failed to supply their environmental targets (Hua et al. 2018), such as the afforestation program aiming at controlling desertification and soil erosion in China, with an investment of 100 billion US\$ and $76 \mathrm{M}$ ha of land afforested (Cao et al. 2011). This means that the paradigm has definitely not shifted yet, and tree planting for climate change mitigation, among many other environmental purposes, is still accomplished following traditional approaches. While new evidences in Europe call for reviewing the main past forest management strategies (Naudts et al. 2016), other studies still prioritize productivity criteria as a way of maximizing carbon sequestration (see in Ennos et al. 2019).

Understanding the consequences of past afforestation programs is paramount to meet the growing demands of ecosystem restoration and rehabilitation and guide forest transitions in the upcoming future. This could be achieved through the revision of the scientific literature synthesizing project results while analyzing the main drivers of observed effects and the ES arising from new tree cover trajectories (Wilson et al. 2017). However, this is a challenging task, as some afforestation programs have been never monitored (e.g. Cortina et al. 2011) or they are monitored 
using inappropriate comparisons (e.g. tree plantations are frequently compared to natural forests, when plantations are mostly established on intensive or degraded land cover types; Stephens and Wagner 2007). In order to avoid negative biases when assessing the efficiency of a tree plantation, the benchmark and controls used should be chosen based on their specific target (e.g. an ecosystem function) or, at least, the land use that is being replaced by the afforestation (Paquette and Messier 2010).

In this work, we have selected Spain as the study area as it has been one of the EU countries with larger areas of land afforested during the last century. In fact, this large-scale afforestation effort was considered rather unique in the world at those times and lead its forest transition (Traugott 1964). As in the rest of Europe, afforestation has been mainly addressed towards an increase of timber production and it has been an important agent of change for the distribution of forest species (McGrath et al. 2015). In this sense, Spain is representative of most of the large-scale afforestation programs of many other developed countries mainly focused on forest productivity. Additionally, the Spanish afforestation policy also sought improving the provision of other regulating ES, such as erosion or hydrological regulation because of the many reservoirs built during those years (Vadell et al. 2016). This is an important asset, as the effectiveness of past afforestation programs could be used to inform current policy agenda that tries meeting multiple goals. In this context, this study was set around two major objectives: (i) assessing the general efficiency of past afforestation policy on the provision of ES and other socio-ecological attributes, and (ii) determining whether the efficiency of the afforestation actions depended on the type of ecosystem against which the plantation is compared. In order to answer these questions we tested the following hypothesis: (i) past afforestation policy improved provisioning ES and socioeconomic aspects but failed on improving regulating ES and biodiversity conservation, and (ii) the efficiency of afforestation depended on the type of vegetation cover (e.g. bare land, pasture, shrubs or natural forests) used to evaluate it.

\section{Materials and methods}

We developed a conceptual framework to analyze the heterogeneous set of studies obtained from a systematic literature review (Fig. 1). As the Spanish afforestation policy has not been systematically monitored, this was necessary to get an objective assessment of restoration goals. Specifically, we evaluated the main outcomes of several afforestation programs by looking at their effects over a group of socioecological attributes sensitive to afforestation actions and related to environmental and social dynamics. The selected afforestation actions were independently considered as samples of a semi-quantitative metaanalysis on which we assessed the change in the benchmark (i.e. a socio-ecological attribute) by means of qualitative response types and sensitivity analyses. Response types were directly extracted from comparisons against other land cover classes made in the selected studies. Each land cover class was classified in different vegetation types according to a degradation-maturity gradient (Table 1). This allowed contrasting not only the efficiency of the afforestation to restore a degraded stand, but also how good afforestation actions were in relation to the ecological properties of a reference condition.

Through this paper we use the term "afforestation" for the deliberate establishment of any tree-dominated vegetation over previous non-forested land and the terms "planted forest" and "plantation" interchangeably, regardless of the method of establishment (cf. FAO 2011).

\section{Study area}

The Spanish afforested area occupies nowadays over $12 \%$ of its territory ( $>5 \mathrm{M}$ ha), with over $60 \%$ of tree cover afforested between 1940 and 1984. The Spanish afforestation policy was articulated by the central public administration towards the regulation of hydrological and erosion processes and timber production. In fact, timber production and regulating-oriented afforestation represented, respectively, 36 and $64 \%$ of the total afforested land (Vadell et al. 2016). This was one of the most important differences with respect to other European countries such as Germany, France or United Kingdom, where timber production prevailed as the main focus of afforestation due to the shortage resulting from the Second World War (Mather 1978; Gadant 1991; Oosthoek 2013; Polley et al. 2014). However, implemented techniques did not differ much, as Spain adapted even-aged plantation forestry, formulated in the forestry schools of France and 


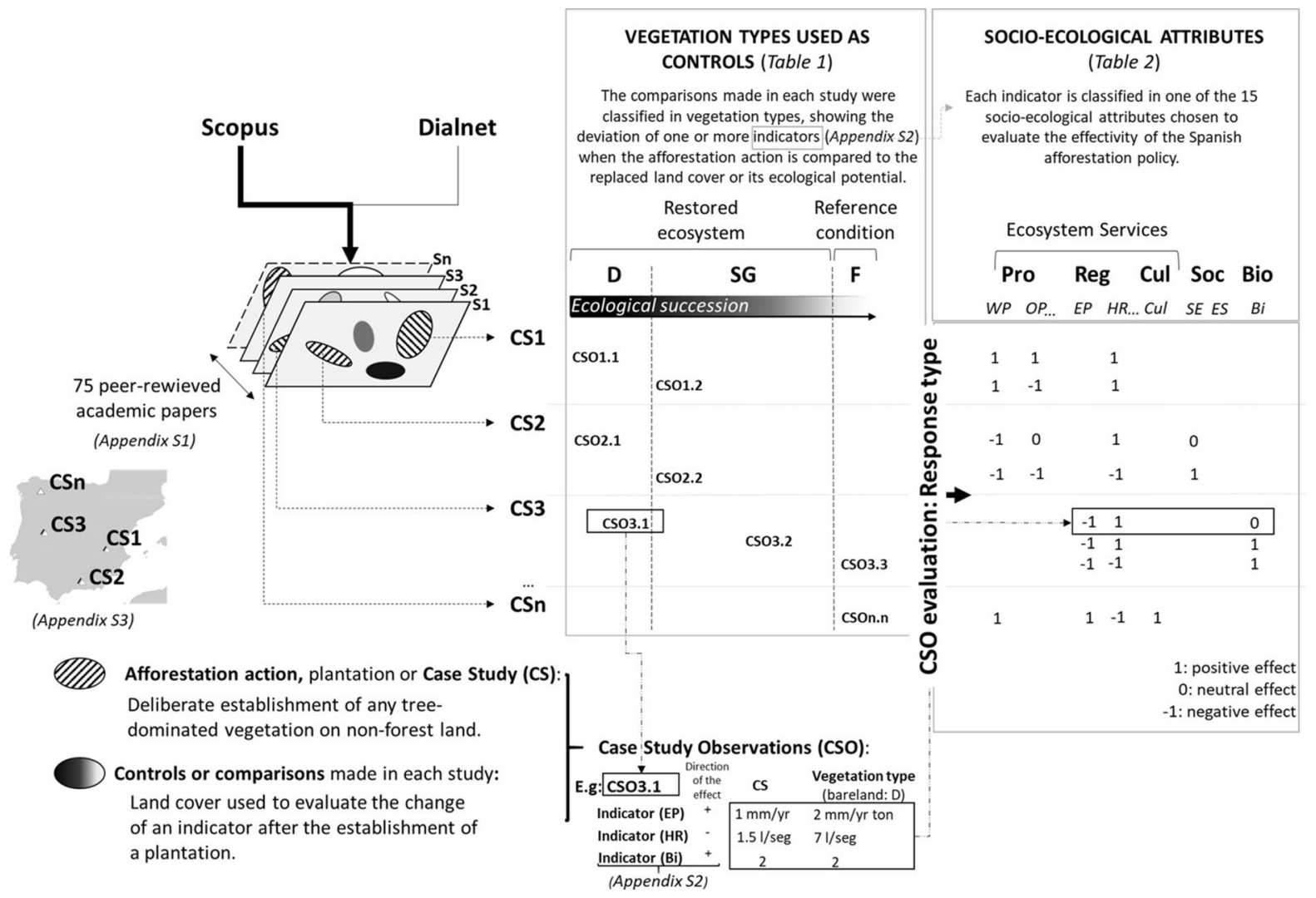

Fig. 1 Flow diagram showing the methodological steps and conceptual framework followed in the study

Table 1 Categories in which the vegetation types used as controls to assess the afforestation effects were divided

\begin{tabular}{llll}
\hline Vegetation type & Type of control & Abbreviation & Land cover typologies included \\
\hline Forest ecosystems & $\begin{array}{c}\text { Reference } \\
\text { (ecological } \\
\text { potential) }\end{array}$ & F & Native forests \\
$\begin{array}{l}\text { Shrubland- } \\
\text { grassland } \\
\text { ecosystems }\end{array}$ & Restored & SG & $\begin{array}{c}\text { Shrublands, grasslands and landscapes in rewilding after abandonment of } \\
\text { traditional uses (i.e. livestock and agricultural) }\end{array}$ \\
$\begin{array}{l}\text { Degraded } \\
\text { ecosystems }\end{array}$ & Restored & D & Agricultural lands, abandoned fields, badlands and barelands \\
\hline
\end{tabular}

Germany, to its complex physical environment in order to satisfy production and regulating goals simultaneously. This interest was mainly shown by the planting of non-native timber trees (e.g. Eucalyptus spp., Monterrey pines or poplar hybrids) in existing woodlands, marginal pastures or agricultural lands and by the establishment of large-scale monospecific plantations (mainly Pinus spp.) on mountain degraded catchments and slopes (Castroviejo et al. 1985).

\section{Literature search}

We performed a systematic review of scientific literature to identify quantitative evidence on the impacts of afforestation on the provision of ES and other socio-ecological attributes. We used two literature databases and focused on publications before October 2019. We searched in the Scopus database for studies including the term "afforestation" in the title, 
abstract or keywords. We limited the affiliation country to Spain, getting 961 published works. We also used Dialnet, one of the widest scientific literature databases of iberoamerican languages, in order to get access to a larger range of Spanish studies. We included the terms "repoblación" or "repoblación forestal" or "reforestación" in their title, abstract or keywords. We limited the affiliation country to Spain, getting 1441 publications. The studies had to meet all the following criteria to be included in the analyses: (i) assessing the effect of at least one afforestation action on a component of the socio-ecological system (e.g. water quality, nutrient cycling, human population dynamics, etc.), and (ii) evaluating the effect by means of one or more indicators showing the deviation of the afforested plot in comparison to the control plot (i.e. a plot with different land cover or vegetation type). We initially scanned all titles and abstracts of selected studies and then read the complete papers when initial scans indicated a potential relevance for the study. In total 75 peer-reviewed studies were retained for further analysis (Appendix S1): 53 from Scopus, 18 from Dialnet and 4 additional publications obtained from cross-references of the previous ones.

Beyond this, each afforestation identified was considered as a case study (CS) whether it has been independently compared to any land cover typology regardless of the type or spatial scale of the comparison or type of study. These and other features as the date, typology and spatial location of the afforestation actions were also collected in order to characterize each CS (Fig. 2). Then, we focused on analysing the effects of the afforestation actions related to the different nature of the land cover typologies used to evaluate them. Thus, each CS was divided in as many observations as different land cover typologies were identified in it (Case Study Observations; CSO). Land cover typologies were categorized in three vegetation types (Table 1): native forest ecosystems (F), shrubland and grassland ecosystems (SG), and degraded ecosystems (D). While $\mathrm{F}$ assesses whether the afforestation would reach the ecological potential of the reference ecosystem, SG and D inform whether the afforestation improves the features of the restored (non-forest) land cover. In total, we evaluated $128 \mathrm{CS}$ that produced $162 \mathrm{CSO}$.
Data extraction

We extracted and analysed measures of different variables (i.e. indicators; Table S2) related to the following socio-ecological attributes: biodiversity (i.e. abundance and diversity of particular species), ES and socioeconomic aspects.

The ES were classified according to the widely applied Common International Classification of Ecosystem Services (CICES) V5.1 (Haines-Young and Potschin 2018). Only a small number of studies referred explicitly to the concept of ES. The identification and classification of the reported indicators were therefore largely made on the basis of expert criteria refined by pair revision among authors (Table S2). The value of the indicator was derived from text, figures or tables of the studies included in the review. One of the CICES' advantages is that it contains a nested hierarchical structure from Section to Division, Group and Class. In our case, this property has been used to make the aggregation of the indicators at each level more flexible in order to have enough data points and statistical power for further analyses. Thus, indicators were grouped in 11 categories; some of them were renamed to adapt it better to the meaning of the evaluation (Table 2). Furthermore, 4 extra categories were added with the purpose of extending the analysis to other interesting components and properties of the socio-ecological system. This were biodiversity, landscape connectivity, social structure and economic structure (Table 2).

The 163 CSO provided 817 measures of socioecological attributes because most studies provided information for more than one ES type, biodiversity and socioeconomic issues.

\section{Response type}

All reviewed studies differed widely in temporal and spatial scale, survey design, evaluated indicators, environmental conditions or measurement procedures. To allow suitable comparisons, all CSO were characterized in a qualitative way. For each of the 15 socioecological attributes on which there was at least one indicator, we evaluated whether each CSO afforestation action produced a positive $(1)$, negative $(-1)$ or neutral effect (0). This assessment was done following three major steps which have been explained in detail in Appendix S3. First, each indicator was classified as 

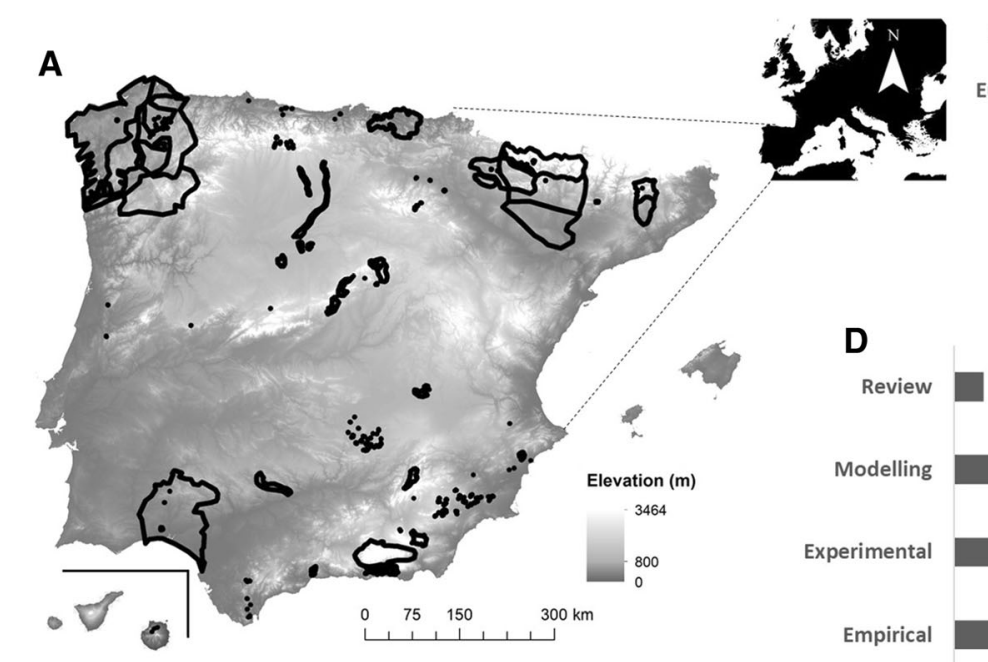

C

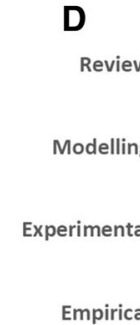

B

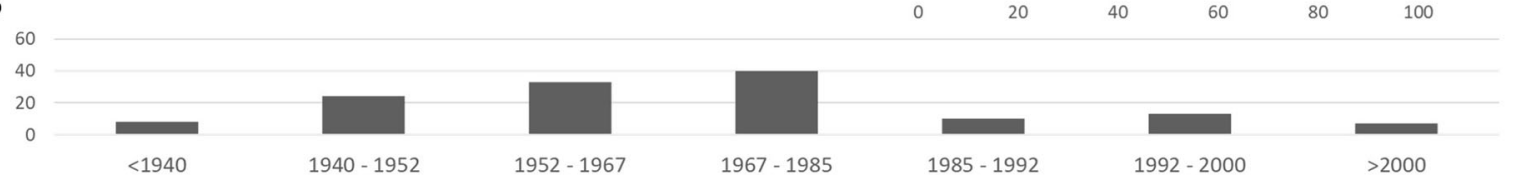

Fig. 2 A Location of the case studies (CS) and number of CS per, $\mathbf{B}$ afforestation date, $\mathbf{C}$ tree species and afforestation objective (light grey- logging; dark grey- hydro-forestry restoration) and $\mathbf{D}$ type of study included in the review

positive, negative or variable depending on the direction of the effect (i.e. response type of the indicator) on the socio-ecological attribute (see Table S2). Second, each indicator was independently evaluated from its comparison, and then classified in positive (1), negative ( -1$)$ or neutral effect (0). Third, when the CSO presented only one indicator to evaluate the socio-ecological attribute, we used it to determine the effect. Otherwise, all the indicators of the same socio-ecological attribute were compared among them in order to determine the most common effect. For this purpose, the indicators were split up in subcomponents of the socio-ecological attribute in order to consider their global contribution (Table S2). The evaluation was firstly done at the subcomponent level and then aggregated to the selected socio-ecological attribute.

\section{Data analysis}

In total, we quantified 409 measures of afforestation actions (CSO) and their effects on the socio-ecological attributes. In order to test the hypotheses of the study we applied two independent statistical analyses for categorical data. To evaluate our first hypothesis, we compared the frequency of response types (positive, negative or neutral) for each socio-ecological attribute with the Chi-square test. The differences between the number of positive and negative cases allowed us estimating the general effect of the afforestation policy on the group of socio-ecological attributes. In this analysis, we only considered the CSO of shrubland and grassland (SG) and degraded (D) vegetation types in order to assess the effect of the afforestation action against to a suitable land cover (i.e. restored ecosystem). To test our second hypothesis, we generated a $3 \times 3$ contingency table per each socio-ecological attribute in order to relate the response type (positive, negative or neutral) to the vegetation type used to evaluate it (F, SG and D). Then we applied a Fisher's exact test. This method has been advised when some of the Chi-square test's assumptions do not meet (i.e. 5 or more expected counts in $80 \%$ of cells and no cells with zero expected counts; McDonald 2014).

\section{Sensitivity analysis}

Evaluation of the response type depended on expert judgement, i.e. the relative importance of each indicator is ultimately related to author's decision. In order to reduce the uncertainty of the results and generate a 
Table 2 Socio-ecological attributes evaluated in the study and number of studies and CS used to assess each attribute

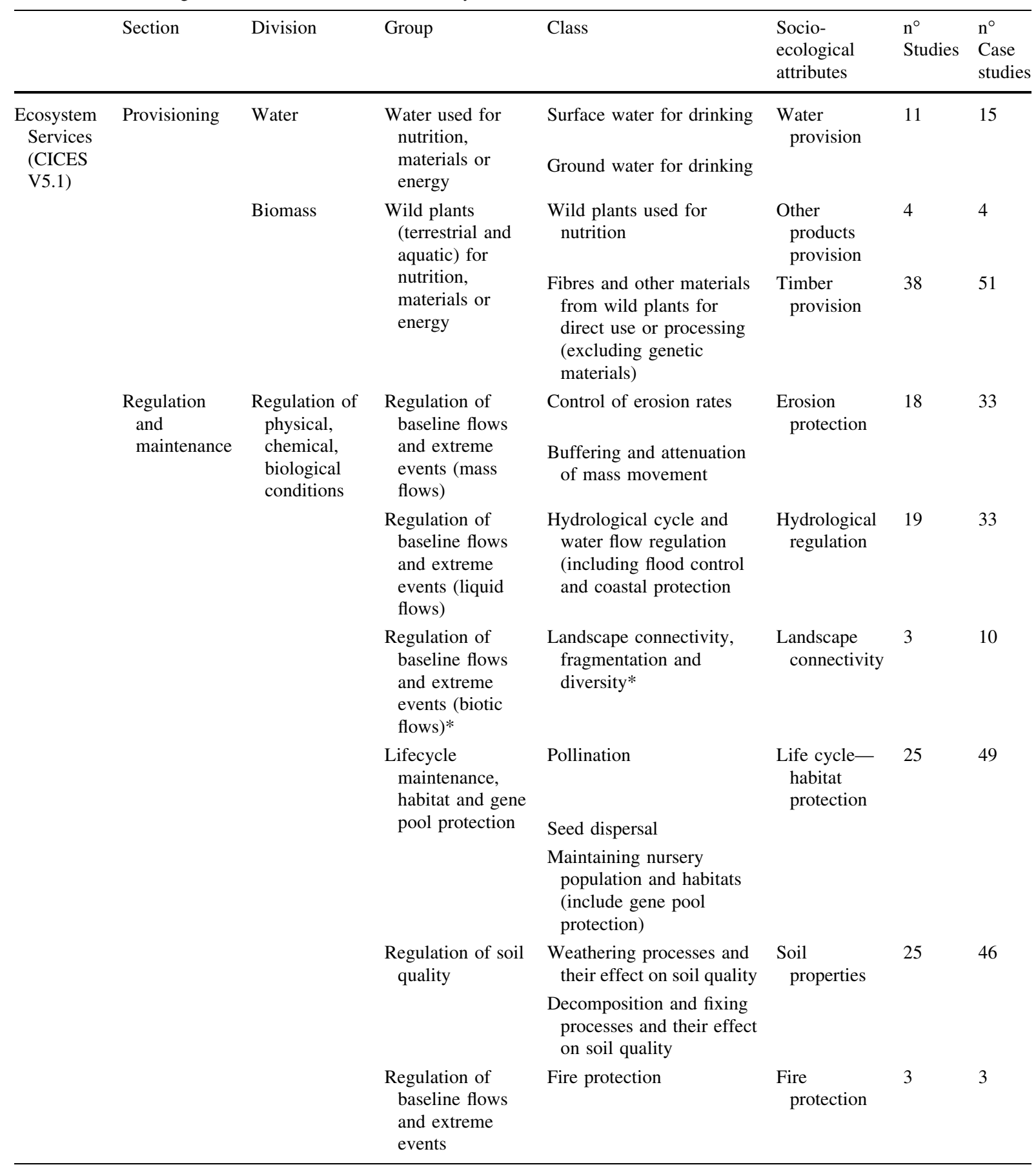


Table 2 continued

\begin{tabular}{|c|c|c|c|c|c|c|c|}
\hline & Section & Division & Group & Class & $\begin{array}{l}\text { Socio- } \\
\text { ecological } \\
\text { attributes }\end{array}$ & $\begin{array}{l}\mathrm{n}^{\circ} \\
\text { Studies }\end{array}$ & $\begin{array}{l}\mathrm{n}^{\circ} \\
\text { Case } \\
\text { studies }\end{array}$ \\
\hline & \multirow{5}{*}{ Cultural } & Water conditions & $\begin{array}{l}\text { Regulation of } \\
\text { the chemical } \\
\text { condition of } \\
\text { freshwaters by } \\
\text { living } \\
\text { processes }\end{array}$ & Freshwater condition & 6 & 12 & \\
\hline & & $\begin{array}{l}\text { Atmosphere } \\
\text { composition and } \\
\text { conditions }\end{array}$ & $\begin{array}{l}\text { Regulation of } \\
\text { chemical } \\
\text { condition of } \\
\text { atmosphere } \\
\text { and oceans }\end{array}$ & Carbon sequestration & 6 & 11 & \\
\hline & & \multirow[t]{3}{*}{$\begin{array}{l}\text { Direct, in-situ and } \\
\text { outdoor interactions } \\
\text { with living systems } \\
\text { that depend on } \\
\text { presence in the } \\
\text { environmental } \\
\text { setting }\end{array}$} & $\begin{array}{l}\text { Physical and } \\
\text { experiential } \\
\text { interactions } \\
\text { with natural } \\
\text { environment }\end{array}$ & $\begin{array}{l}\text { Characteristics of living } \\
\text { systems that enable } \\
\text { activities promoting } \\
\text { health, recuperation or } \\
\text { enjoyment through } \\
\text { active or immersive } \\
\text { interactions }\end{array}$ & Social value & 7 & 7 \\
\hline & & & $\begin{array}{l}\text { Intellectual and } \\
\text { representative } \\
\text { interactions } \\
\text { with natural } \\
\text { environment }\end{array}$ & $\begin{array}{l}\text { Characteristics of living } \\
\text { systems that are } \\
\text { resonant in terms of } \\
\text { culture or heritage }\end{array}$ & & & \\
\hline & & & $\begin{array}{l}\text { Characteristics } \\
\text { of living } \\
\text { systems that } \\
\text { enable } \\
\text { aesthetic } \\
\text { experiences }\end{array}$ & & & & \\
\hline \multirow[t]{2}{*}{$\begin{array}{l}\text { Socioeconomic } \\
\text { aspects }\end{array}$} & \multirow[t]{2}{*}{-} & \multirow[t]{2}{*}{-} & \multirow[t]{2}{*}{-} & Social structure* & $\begin{array}{l}\text { Social } \\
\text { structure }\end{array}$ & 8 & 8 \\
\hline & & & & Economic structure* & $\begin{array}{r}\text { Economic } \\
\text { structure }\end{array}$ & 10 & 15 \\
\hline Biodiversity* & - & - & - & - & Biodiversity & 6 & 8 \\
\hline
\end{tabular}

Mostly of the evaluated attributes are ecosystem services from CICES V5.1, but other as biodiversity and socioeconomic aspects (*) were also included. The hierarchy level of CICES in which the indicators of evaluation were aggregated are highlighted in grey

more objective expert-driven data evaluation, we reanalysed the effects of the afforestation actions on the socio-ecological attributes by assigning a set of weights to each indicator instead of a single value. For this purpose, we repeated the "response type" and "data analysis" processes 1500 times. At each iteration, we randomly assigned a value from a specific range (from 0.25 to 1.75 in steps of 0.25 ) to each indicator. Finally, we looked at the changes of p-value with respect to the results of a single expert-driven process.

\section{Results}

Out of the 129 CS compiled, $78 \%$ were pines, $6 \%$ poplars and $15 \%$ Eucalyptus plantations. Likewise, $67 \%$ of them were considered as hydro-forestry restoration, while the rest had mainly productive purposes. A total of $62 \%$ of the CS corresponded to afforestation actions made between the years 1940 and 1985. Finally, 75\% of CSs were younger than 50 years when they were evaluated (Fig. 2). 
Effects of the afforestation on the socio-ecological attributes

Afforestation had a significant negative impact on 6 out of the 15 socio-ecological attributes explored (40\%; Fig. 3): water provision, hydrological regulation, life cycle-habitat protection, soil properties, social structure and biodiversity. Significant positive effects were only reported in 2 of the 15 socioecological attributes (13\%; Fig. 3): timber provision and carbon sequestration. Sensitivity analysis showed changes in the p-value of 4 of the 15 socio-ecological attributes (Fig. S4A). However, only in hydrological regulation and social value the level of significance changed to non-significant.
In the supply of provisioning and cultural ES, the number of positive CSOs were larger than the sum of negative and neutral effects (68 and $75 \%$ of positive cases respectively; Fig. 3A, C). The rest of the groups accumulated $40 \%$ (regulating ES; Fig. 3B), $40 \%$ (socioeconomic aspects; Fig. 3D) and 31\% (biodiversity; Fig. 3E) of positive CSOs.

The effect of vegetation types used to evaluate afforestation efficiency

There were not significant differences in afforestation efficiency between the three vegetation types used to assess it in the groups of provisioning and cultural ES (Fig. 4A, C, respectively). In opposition, there were

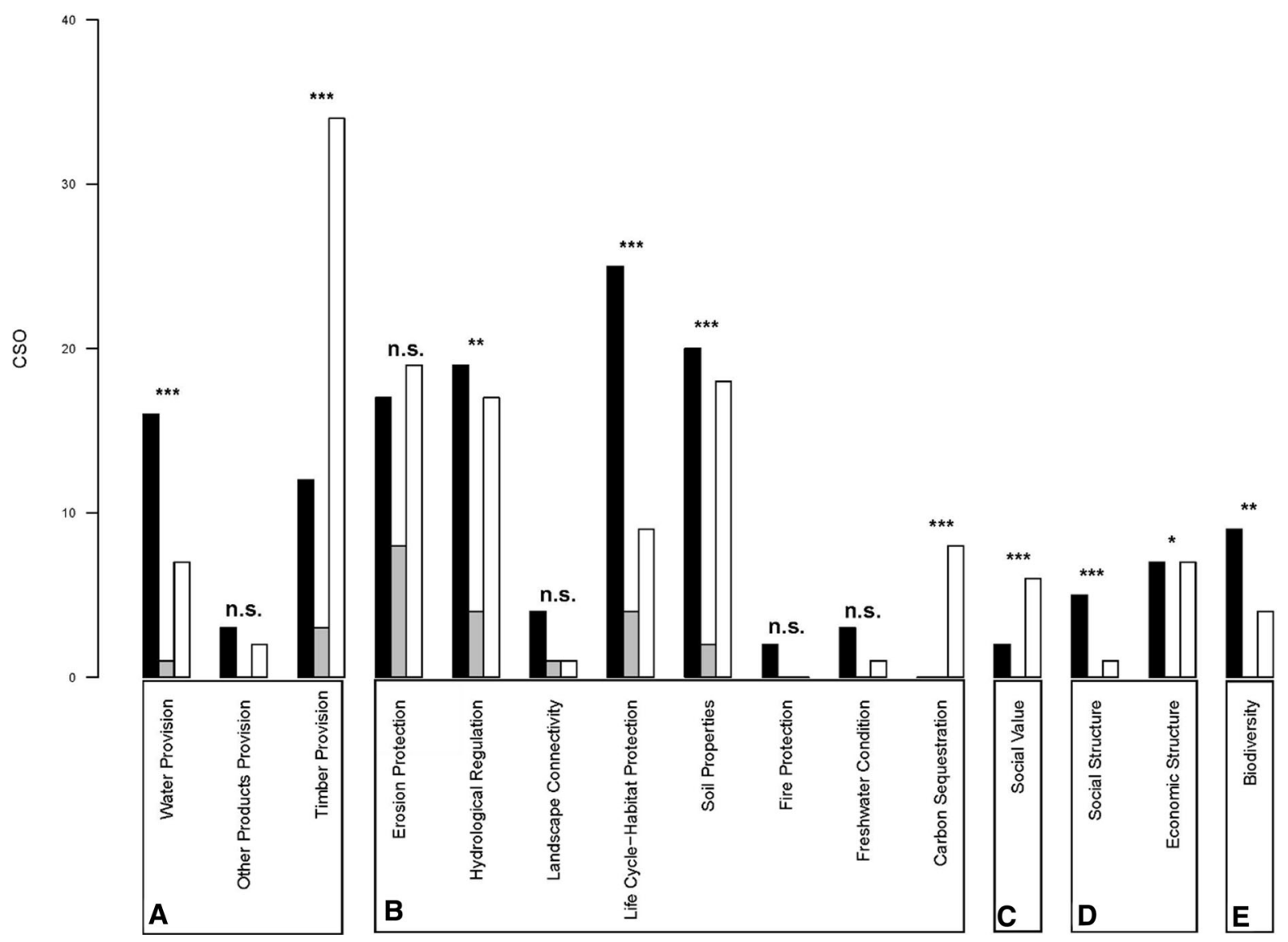

Fig. 3 Frequencies of case study observations (CSO) effects (positive in white, negative in black and neutral in grey) on the socio-ecological attributes considered in this study. We only considered the CSO of restored type of controls ( $S G$ shrubland and grassland ecosystems and $D$ degraded ecosystems).
Significant differences in the frequencies of response types within a socio-ecological attributes are tested with a Chisquared test $($ d.f. $=2)$ and indicated by asterisks $(* p<0.05$, $* * \mathrm{p}<0.01, * * * \mathrm{p}<0.001$ and n.s. $\mathrm{p}>0.05)$ 
significant differences in afforestation efficiency between the three vegetation types used to assess it in $50 \%$ of regulating ES: erosion $(\mathrm{p}=0.005)$, hydrological regulation $(\mathrm{p}=0.024)$, soil properties $(\mathrm{p}<0.001)$ and carbon sequestration $(\mathrm{p}=0.007)$. In these cases, positive effects of afforestation were lower when the vegetation type in the control plot was natural forest $(\mathrm{F})$. Furthermore, excluding carbon sequestration, positive responses were higher when afforestation was compared to degraded ecosystems (D) than in shrubland and grassland ecosystems (SG; Fig. 4B). There were not significant differences when evaluating socioeconomic aspects or biodiversity (Fig. 4D, E respectively). Finally, the sensitivity analysis showed only a slight difference in the p-value of hydrological regulation (from $\mathrm{p}<0.05$ to nonsignificant in 869 iterations; Fig. S4 B).

\section{Discussion}

In this work, we performed a meta-analysis identifying the main effects of past large-scale afforestation programs on the provision of ES and other socioecological attributes. Our first hypothesis was confirmed as the afforestation programs improved provisioning ES but not regulating ES, biodiversity conservation or socioeconomic aspects. Our second hypothesis was also confirmed since the efficiency of
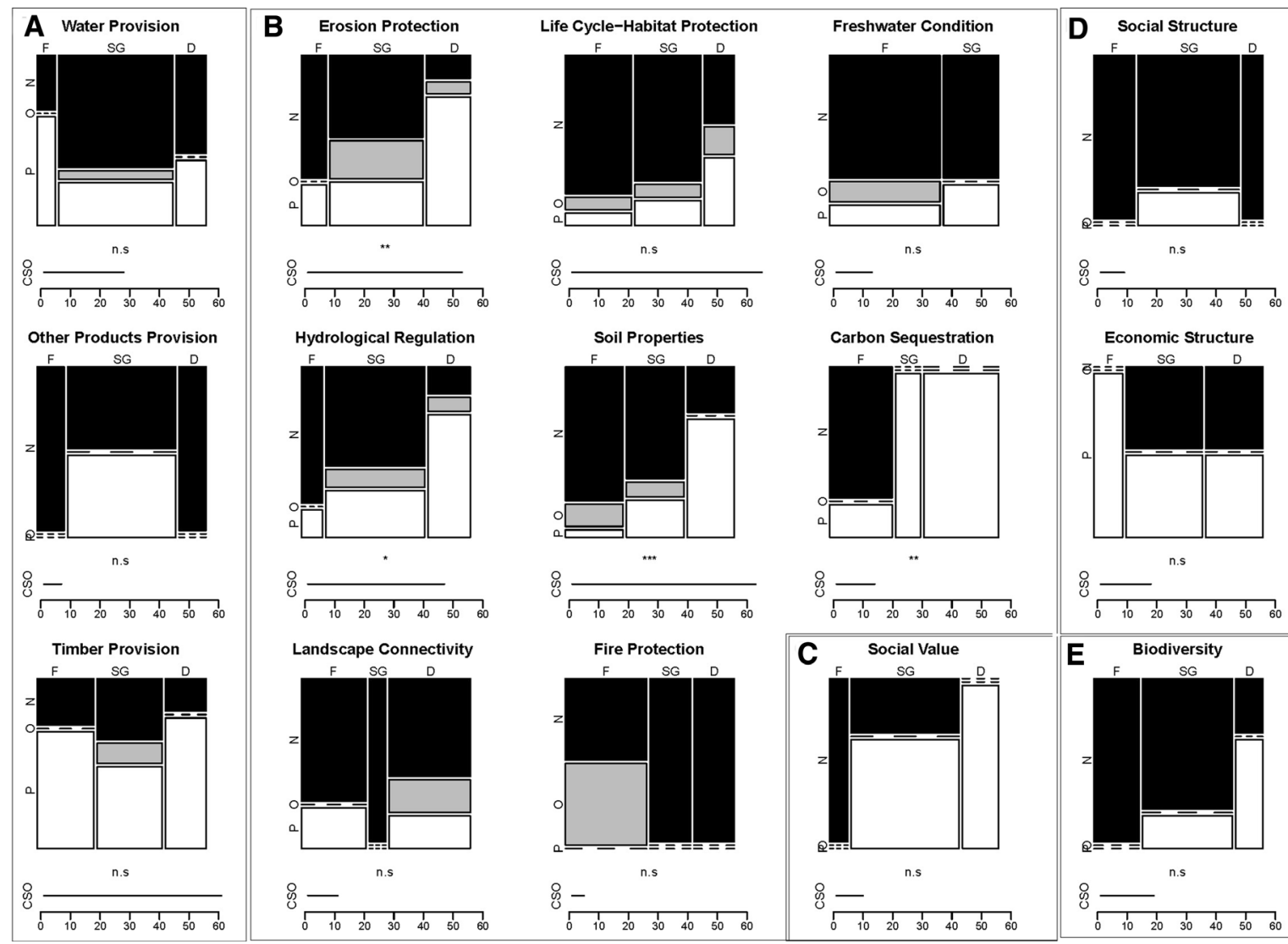

Fig. 4 Mosaic plots for the effect of a case study observation (CSO) on socio-ecological attributes ( $P$ positive in white, $N$ negative in black and $O$ neutral in grey), the vegetation type used in this CSO is also shown ( $F$ forest ecosystems, $S G$ shrubland and grassland ecosystems and $D$ degraded ecosystems). Mosaic plots are grouped in types of socio-ecological attributes (A provisioning ecosystem services, B regulation ecosystem services, C cultural ecosystem services,

D socioeconomic aspects and $\mathbf{E}$ biodiversity) representing the counts in contingency tables by tiles. The size of the tile is proportional to the cell count. Significant differences in the response types among vegetation types within a socio-ecological attribute are tested with a Fischer's exact test and indicated by asterisks $(* \mathrm{p}<0.05, * * \mathrm{p}<0.01$, ***p $<0.001$ and n.s. $\mathrm{p}>0.05$ ). The number of CSO used to evaluate each socioecological attribute is also presented under each mosaic plot 
afforestation actions depends on the type of vegetation used for comparison.

Trade-offs between ES provisioning

Past afforestation policy produced a significant positive effect on timber provision (Fig. 3A) and carbon sequestration (Fig. 3B). This result is mainly related to the dominant use of fast-growing species (Vadell et al. 2016), which also led to trade-offs with regulating ES (Fig. 3B). These monospecific plantations use larger quantities of water (van Dijk and Keenan 2007) and they hamper natural vegetation colonization and species settling by sprouting or seedling (RomeroAlcaraz and Ávila 2000; Chirino et al. 2006). This produces a depletion of biodiversity and associated ecological functions. Regarding hydrological regulation, successful plantations usually improved hydrological responses at the catchment scale. However, the common use of hard techniques for hydric control and soil preparation (e.g. slope terracing) to reduce costs and to plant in constrained environments contributed to increase the number of negative CSO (Ortigosa et al. 1990). In many cases, these techniques also reactivated slope erosion processes and soil losses (Romero-Diaz et al. 2010). In others they simply produced negative effects on physical and chemical soil properties, together with a lower quality of the organic matter provided by the planted species to the topsoil (Ternan et al. 1996; Cristina Zancada et al. 2003).

Cultural ES improved with afforestation (Fig. 3C) by means of increasing social values in areas without a specific target or previous economic activity that avoids stakeholder interests to keep previous land cover and use types (Derak and Cortina 2014). Furthermore, afforestation made on severely degraded areas improved people's perception about water flow, erosion regulation and aesthetic values (García Pérez et al. 1995). However, this group of ES should be carefully considered due to the highly context-dependence of their indicators (Derak and Cortina 2014; Fig. S4 A).

Finally, past afforestation policy produced negative effects on socioeconomic aspects (Fig. 3D), although economic benefits might have been underestimated in our analysis by assessing only two CSO with Eucalyptus plantations. Among the most remarkable negative effects on the society domain, large-scale afforestation programs were considered as a catalyst of rural exodus in several Spanish mountain depressed regions (Chauvelier 1990; Fernández-Muñoz 2002). In these areas, the demand for land to afforest caused deep socioeconomic changes in the former agrarian uses that led to the abandonment of traditional activities. Conversely, land use intensification in lowlands promoted landscape mosaics in where productive plantations usually produced higher incomes than the replaced land use (e.g. Rodríguez-Loinaz et al. 2013). However, low-income farmers were unable of modernizing their production system and frequently also forced to shut down (Marey-Pérez and Rodríguez-Vicente 2009).

\section{Afforestation programs versus regulating ES}

Regulating ES are related to functions arising from ecosystem stability, maturity and structural diversity (Odum 1969), which are also positive correlated with biodiversity patterns (Balvanera et al. 2006; Rey Benayas et al. 2009). Similarly, our results indicate that regulating ES were dependent on the vegetation type used to assess the efficiency of afforestation (Fig. 4B). Firstly, since the provision of regulating ES is closely related to the maturity of the ecosystems, vegetation typologies that are more advanced in the ecological succession are significantly more restrictive. This means that the success of an afforestation action decreases from control plots with degraded ecosystems (D) to shrubland and grassland ecosystems (SG) or native forests (F). Life cycle-habitat protection and biodiversity (Fig. 4B, E respectively) showed the same pattern, although the great number of negative cases under SG and D categories prevented finding significant differences.

The significant differences encountered for regulating ES and biodiversity when comparing to $\mathrm{F}$ and $\mathrm{D}$ vegetation types are in agreement with previous studies (Stephens and Wagner 2007; Bauhus et al. 2010; Brockerhoff et al. 2013). We observed that plantations improved the benchmarks in degraded and intensively managed land, but they usually provide lower values of regulating ES compared to native forests. Moreover, afforestation actions did not improve regulating ES when compared to SG vegetation types. This confirms that afforested land may follow slower or undesired restoration trajectories that would not reach the functional levels of the reference 
condition (F) or even previous stages of ecological succession (SG) (Chazdon et al. 2016). In other words, the observed failures of some afforestation actions for improving the provisioning of regulating ES can be related to the application of non-effective restoration techniques but also to their negative impacts on biodiversity and community dynamics. Furthermore, Mediterranean related ecosystems are highly hampered by climate and other abiotic constraints and forest could not be always the reference target of ecological restoration (Cortina et al. 2006). Afforestation may then represent a perturbation producing a regression in some functional properties (Chirino et al. 2001; Maestre et al. 2003).

Lessons learnt: from afforestation programs to landscape planning

Our study encompasses a great variability in bioclimatic, topographical, geological and socioeconomic conditions because of the large environmental heterogeneity of the Iberian Peninsula (Rey Benayas and Scheiner 2002). Most of the revised afforestation actions focused on timber production as underlying goal, in opposition to a more comprehensive ecological functioning restoration. This is also the case for most of the large-scale afforestation programs carried out in developed countries during the twentieth century (Zanchi et al. 2007; Tal and Gordon 2010; Bradshaw 2012; McGrath et al. 2015). Therefore, an extrapolation of the main results can be reliable at a pan European or at least Mediterranean scale (Rudel et al. 2005), especially for mountainous regions (Fig. S5). Moreover, these lessons learnt can be particularly interesting for countries that are currently experiencing similar forest transitions (e.g. Vietnam and Thailand; Wilson et al. 2017). In this sense, the sensitivity analysis carried out precluded expert biases, reinforcing the consistency of our results. In fact, similar worldwide studies (e.g. Gerrand et al. 2003; Tak et al. 2007; Cao et al. 2011) give support to our initial hypothesis that the investment on afforestation for timber production is not an effective strategy for improving regulating ES and biodiversity at a large-scale (Bennett et al. 2009). However, recovering the full list of species of primary forests (i.e. alpha diversity) in a restored forest is not necessary to enhance many regulating services (Lamb 2018). Reliable win-win strategies to improve the provisioning of multiple ES should be chosen to warrant multifunctionality at a landscape scale in an affordable manner. For example, by using different species mixtures at different spatial extents (Pasari et al. 2013) and fostering the conservation of key ecosystem components.

Consequently, large-scale afforestation programs should be integrated into broader spatial planning instruments, such as Green Infrastructure Network schemes (GIN; Benedict and McMahon, 2012), in order to: (i) optimize biodiversity and multifunctionality at the landscape scale and (ii) control trade-offs among bundles of ES. In this sense, commercial forest plantations can be potentially incorporated to the GIN strategy to generate provisioning ES (e.g. timber production) if their spatial extent, location and techniques applied are suitable also for other purposes related to sensitive regulating ES. If not, additional measures should be implemented when afforestation trade-offs are detected (e.g. green filters of natural vegetation in peripheral areas of fast growing tree plantations; Thompson et al. 2011). Conversely, afforestation projects focusing on recovering species-richness or provisioning of regulating ES could be promoted through passive restoration of native vegetation or active restoration of particular vegetation traits.

\section{Conclusions}

Since the beginning of the twentieth century, a huge amount of money and effort has been addressed towards the afforestation of degraded territories. Afforestation methods and strategies have shifted as scientific knowledge and society perspectives evolve and, thus, the analysis of main outcomes of past afforestation policies can provide useful information to tackle future challenges. Our study shows the difficulties of ensuring the provisioning of regulating ES when timber provisioning or carbon sequestration are prioritized at broad scales. In these cases, the productivity target usually conditions the design and management of tree plantations and clear trade-offs could appear as a consequence of biodiversity losses but also because of the impacts on soil properties and the entire ecosystem functioning and dynamics. In fact, past large-scale afforestation programs only improved the provision of regulating ES when 
compared to highly degraded or intensively managed areas. Thus, our study shows that new forest restoration and rehabilitation programs should also consider fostering successional trajectories towards an ideal state that allows recovering important biophysical processes and ecosystem components related to the provision of regulating ES and biodiversity patterns. As a consequence, any new large-scale afforestation program should be implemented under more comprehensive landscape approaches that allow reducing undesired ES trade-offs and getting multiple objectives while managing different type of ecosystems. These approaches allow defining appropriate mechanisms to assemble active and passive restoration actions, tree commercial planting and other alternatives in cost-effective ways that enable achieving multifunctional landscapes and ensuring biodiversity conservation under uncertain scenarios of Global Change.

Author Contributions IPS and JB conceived the ideas and designed methodology; IPS implemented the database and conducted the analyses, with substantial input from JMAM; IPS led the writing; all authors discussed the results and commented on the manuscript.

Funding Ignacio Pérez Silos is supported by a predoctoral research grant (Ref: FPU-2015-03018) from the Spanish Ministry of Economy and Competitiveness. This research was partially funded by the European Regional Development Fund through the Interreg Atlantic Area as part of the ALICE project, Grant/Award Number (EAPA-261/2016). Open Access funding provided thanks to the CRUE-CSIC agreement with Springer Nature.

Data Availability The primary datasets used in this study are available for the whole study area as online data support.

\section{Declarations}

Conflict of interest The authors declare no conflict of interest.

Consent for publication The authors consent the publication of the study.

Open Access This article is licensed under a Creative Commons Attribution 4.0 International License, which permits use, sharing, adaptation, distribution and reproduction in any medium or format, as long as you give appropriate credit to the original author(s) and the source, provide a link to the Creative Commons licence, and indicate if changes were made. The images or other third party material in this article are included in the article's Creative Commons licence, unless indicated otherwise in a credit line to the material. If material is not included in the article's Creative Commons licence and your intended use is not permitted by statutory regulation or exceeds the permitted use, you will need to obtain permission directly from the copyright holder. To view a copy of this licence, visit http://creativecommons.org/licenses/by/4.0/.

\section{References}

Alexander S, Nelson CR, Aronson J, Lamb D, Cliquet A, Erwin KL, Finlayson CM, De Groot RS, Harris JA, Higgs ES, Hobbs RJ, Robin Lewis RR, Martinez D, Murcia C (2011) Opportunities and challenges for ecological restoration within REDD+. Restor Ecol 19(6):683-689. https://doi. org/10.1111/j.1526-100X.2011.00822.x

Álvarez-Martínez JM, Suárez-Seoane S, Stoorvogel JJ, de Luis Calabuig E (2014) Influence of land use and climate on recent forest expansion: a case study in the EurosiberianMediterranean limit of north-west Spain. J Ecol 102(4):905-919. https://doi.org/10.1111/1365-2745.12257

Balvanera P, Pfisterer AB, Buchmann N, He JS, Nakashizuka T, Raffaelli D, Schmid B (2006) Quantifying the evidence for biodiversity effects on ecosystem functioning and services. Ecol Lett 9:1146-1156. https://doi.org/10.1111/j.14610248.2006.00963.x

Bauhus J, van der Meer P, Kanninen M (eds) (2010) Ecosystem goods and services from plantation forests. Earthscan, Routledge

Benedict MA, McMahon ET (2012) Green infrastructure: linking landscapes and communities. Island press, Washington

Bennett EM, Peterson GD, Gordon LJ (2009) Understanding relationships among multiple ecosystem services. Ecol Lett 12(12):1394-1404. https://doi.org/10.1111/j.1461-0248. 2009.01387.x

Bonan GB (2008) Forests and climate change: forcings, feedbacks, and the climate benefits of forests. Science 320(5882):1444-1449. https://doi.org/10.1126/science. 1155121

Bongaarts J (2007) Ecosystems and human well-being: volume 1, current state and trends. In: Hassan R, Scholes R, Ash N (eds) Population and development review. Overseas Development Institute, London

Bradshaw CJA (2012) Little left to lose: Deforestation and forest degradation in Australia since European colonization. J Plant Ecol 5(1):109-120. https://doi.org/10.1093/ jpe/rtr038

Brockerhoff EG, Jactel H, Parrotta JA, Ferraz SFB (2013) Forest ecology and management role of eucalypt and other planted forests in biodiversity conservation and the provision of biodiversity-related ecosystem services. For Ecol Manage 301:43-50. https://doi.org/10.1016/j.foreco.2012.09.018

Cao S, Chen L, Shankman D, Wang C, Wang X, Zhang H (2011) Excessive reliance on afforestation in China's arid and semi-arid regions: lessons in ecological restoration. Earth Sci Rev 104(4):240-245. https://doi.org/10.1016/j. earscirev.2010.11.002

Castroviejo S, García Dory, MA, Martínez S, Prieto F (1985) Política forestal en España: producción o conservación? Arbor 
Chauvelier F (1990) La repoblación forestal en la provincia de Huesca y sus impactos geográficos. Instituto de Estudios Alto Aragoneses

Chazdon R, Brancalion P (2019) Restoring forests as a means to many ends. Science 365(6448):24-25

Chazdon R, Brancalion P, Laestadius L, Bennett-Curry A, Buckingham K, Kumar C, Moll-Rocek J, Vieira I, Wilson $S$ (2016) When is a forest a forest? Forest concepts and definitions in the era of forest and landscape restoration. Ambio 45(5):538-550. https://doi.org/10.1007/s13280016-0772-y

Chirino E, Bonet A, Bellot J, Sánchez JR (2006) Effects of 30-year-old Aleppo pine plantations on runoff, soil erosion, and plant diversity in a semi-arid landscape in south eastern Spain. CATENA 65(1):19-29. https://doi.org/10.1016/j. catena.2005.09.003

Chirino E, Sánchez JR, Bonet A, Bellot J (2001) Effects of afforestation and vegetation dynamics on soil erosion in a semi-arid environment (SE Spain), Advances in Ecological Sciences, 10: 239-248. http://www.scopus.com/inward/ record.url?eid=2-s2.0-1542311920\&partnerID=40\&md5= 8f6fdbb073aa4d85a21db9deab5fed47

Cortina J, Amat B, Castillo V, Fuentes D, Maestre FT, Padilla FM, Rojo L (2011) The restoration of vegetation cover in the semi-arid Iberian southeast. J Arid Environ 75(12):1377-1384. https://doi.org/10.1016/j.jaridenv. 2011.08 .003

Cortina J, Maestre FT, Vallejo R, Baeza MJ, Valdecantos A, Pérez-Devesa M (2006) Ecosystem structure, function, and restoration success: are they related? J Nat Conserv 14:152-160. https://doi.org/10.1016/j.jnc.2006.04.004

Cristina Zancada M, Almendros G, Jiménez Ballesta R (2003) Humus quality after eucalypt reforestations in Asturias (Northern Spain). Sci Total Environ 313:245-258. https:// doi.org/10.1016/S0048-9697(03)00255-9

Derak M, Cortina J (2014) Multi-criteria participative evaluation of Pinus halepensis plantations in a semiarid area of southeast Spain. Ecol Ind 43:56-68. https://doi.org/10. 1016/j.ecolind.2014.02.017

Doelman JC, Stehfest E, van Vuuren DP, Tabeau A, Hof AF, Braakhekke MC, Gernaat DEHJ, van den Berg M, van Zeist WJ, Daioglou V, van Meijl H, Lucas PL (2020) Afforestation for climate change mitigation: potentials, risks and trade-offs. Glob Change Biol 26(3):1576-1591. https://doi.org/10.1111/gcb.14887

Dr. Polley H, Hennig P, Kroiher F, Marks A, Dr. Riedel T, Schmidt U, Schwitzgebel F, Stauber T (2014) The forest in Germany. 56. https://www.bmel.de/SharedDocs/ Downloads/EN/Publications/ForestsInGermany-BWI. pdf?_blob=publicationFile

Ennos R, Cottrell J, Hall J, Brien DO (2019) Forest ecology and management Is the introduction of novel exotic forest tree species a rational response to rapid environmental change? A British perspective. Forest Ecol Manage 432:718-728. https://doi.org/10.1016/j.foreco.2018.10.018

FAO (2011) State of the world's forests. Food and Agriculture Organization of the United Nations, Rome

Fernández-Muñoz S (2002) Consecuencias socioeconómicas y territoriales de las repoblaciones forestales en el Alto Sorbe (Guadalajara). Eria 58:183-203
Gadant J (1991) France's forests. In: Dembner SA (ed) An international journal of forestry and forest industries. FAO, Rome

Garcia Perez JD, Charlton C, Martin Ruiz P (1995) Landscape changes as visible indicators in the social, economic and political process of soil erosion: a case study of the municipality of puebla de valles (Guadalajara Province) Spain. Land Degrad Develop 6(3):149-161. https://doi. org/10.1002/ldr.3400060303

Gerber F (2011) Conflicts over industrial tree plantations in the South: who, how and why? Glob Environ Chang 21:165-176. https://doi.org/10.1016/j.gloenvcha.2010.09. 005

Gerrand A, Keenan RJ, Kanowski P, Stanton R (2003) Australian forest plantations: an overview of industry, environmental and community issues and benefits. Aust for 66(1):1-8. https://doi.org/10.1080/00049158.2003. 10674881

Grainger A, Boucher DH, Frumhoff PC, Laurance WF, Lovejoy T, McNeely J, Niekisch M, Raven P, Sodhi NS, Venter O, Pimm SL (2009) Biodiversity and REDD at copenhagen. Curr Biol 19(21):974-976. https://doi.org/10.1016/j.cub. 2009.10.001

Haines-Young R, Potschin M (2018) CICES V5. 1. Guidance on the application of the revised structure. Fabis Consulting, England

Hua F, Wang L, Fisher B, Zheng X, Wang X, Yu DW, Tang Y, Zhu J, Wilcove DS (2018) Tree plantations displacing native forests: the nature and drivers of apparent forest recovery on former croplands in Southwestern China from 2000 to 2015. Biol Cons 222:113-124. https://doi.org/10. 1016/j.biocon.2018.03.034

Lamb D (2014) Large-scale forest restoration. Earthscan, Rouledge

Lamb D (2018) Undertaking large-scale forest restoration to generate ecosystem services. Restor Ecol 26(4):657-666. https://doi.org/10.1111/rec.12706

Lamb D, Erskine PD, Parrotta JA (2005) Restoration of degraded tropical forest landscapes. Science 310(5754):1628-1632. https://doi.org/10.1126/science. 1111773

Maestre FT, Cortina J, Bautista S, Bellot J (2003) Does Pinus halepensis facilitate the establishment of shrubs in Mediterranean semi-arid afforestations? For Ecol Manage 176(1-3):147-160. https://doi.org/10.1016/S03781127(02)00269-4

Marey-Pérez MF, Rodríguez-Vicente V (2009) Forest transition in Northern Spain: local responses on large-scale programmes of field-afforestation. Land Use Policy 26(1):139-156. https://doi.org/10.1016/j.landusepol.2008. 02.004

Mather AS (1978) Patterns of afforestation in Britain since 1945. Geography 63(3):157-166

Mather AS (1992) The forest transition. The Royal Geographical Society 24(4):367-379

McDonald JH (2014) Handbook of biological statistics. Sparky House Publishing, Baltimore

McGrath MJ, Luyssaert S, Meyfroidt P, Kaplan JO, Bürgi M, Chen Y, Erb K, Gimmi U, McInerney D, Naudts K, Otto J, Pasztor F, Ryder J, Schelhaas MJ, Valade A (2015) Reconstructing European forest management from 1600 to 
2010. Biogeosciences 12(14):4291-4316. https://doi.org/ 10.5194/bg-12-4291-2015

Meyfroidt P, Lambin EF (2011) Global forest transition: prospects for an end to deforestation. Annu Rev Environ Resour 36:343-371. https://doi.org/10.1146/annurevenviron-090710-143732

Naudts K, Chen Y, McGrath MJ, Ryder J, Valade A, Otto J, Luyssaert S (2016) Forest management: Europe's forest management did not mitigate climate warming. Science 351(6273):597-599. https://doi.org/10.1126/science. $\operatorname{aad} 7270$

Odum EP (1969) The strategy of ecosystem development. Science 164(3877):262-270

Oosthoek, K. J. (2013). Scottish forestry in the 19th century. Conquering the Highlands, pp 33-50. http://www.jstor. org/stable/j.ctt2jbkm4.11

Ortigosa LM, Garcia-Ruiz JM, Gil-Pelegrin E (1990) Land reclamation by reforestation in the central pyrenees. Mt Res Dev 10(3):281-288. https://doi.org/10.2307/3673607

Paquette A, Messier C (2010) The role of plantations in managing the world's forests in the Anthropocene. Front Ecol Environ 8(1):27-34. https://doi.org/10.1890/080116

Pasari JR, Levi T, Zavaleta ES, Tilman D (2013) Several scales of biodiversity affect ecosystem multifunctionality. Proceedings Natl Acad Sci 21:1-4. https://doi.org/10.1073/ pnas. 1220333110

Pongratz J, Reick C, Raddatz T, Claussen M (2008) A reconstruction of global agricultural areas and land cover for the last millennium. Global Biogeochem Cycles. https://doi. org/10.1029/2007GB003153

Rey Benayas JM, Newton AC, Diaz A, Bullock JM (2009) Enhancement of biodiversity and ecosystem services by ecological restoration: a meta-analysis. Science 325(5944):1121-1124. https://doi.org/10.1126/science. 1172460

Rey Benayas JM, Scheiner SM (2002) Plant diversity, biogeography and environment in Iberia: patterns and possible causal factors. J Veg Sci 13(2):245-258. https://doi.org/10. 1111/j.1654-1103.2002.tb02045.x

Rodríguez-Loinaz G, Amezaga I, Onaindia M (2013) Use of native species to improve carbon sequestration and contribute towards solving the environmental problems of the timberlands in Biscay, northern Spain. J Environ Manage 120:18-26. https://doi.org/10.1016/j.jenvman.2013.01.032

Romero-Alcaraz E, Ávila JM (2000) Landscape heterogeneity in relation to variations in epigaeic beetle diversity of a Mediterranean ecosystem. Implic Conserv Biodivers Conserv 9(7):985-1005. https://doi.org/10.1023/A: 1008958720008

Romero-Diaz A, Belmonte-Serrato F, Ruiz-Sinoga JD (2010) The geomorphic impact of afforestations on soil erosion in southeast Spain. Land Degrad Dev 21(2):188-195. https:// doi.org/10.1002/ldr.946

Rudel TK, Coomes OT, Moran E, Achard F, Angelsen A, Xu J, Lambin E (2005) Forest transitions: towards a global understanding of land use change. Glob Environ Chang 15:23-31. https://doi.org/10.1016/j.gloenvcha.2004.11. 001

Rudel TK, Meyfroidt P, Chazdon R, Bongers F, Sloan S, Grau HR, Holt TV, Schneider L (2020) Whither the forest transition? Climate change, policy responses, and redistributed forests in the twenty-first century. Ambio 49(1):74-84. https://doi.org/10.1007/s13280-018-01143-0

Sedjo RA (1999) The potential of high-yield plantation forestry for meeting timber needs: recent performance, future potentials, and environmental implications. New for 17(1-3):339-359. https://doi.org/10.1007/978-94-0172689-4_21

Song X, Hansen MC, Stephen V, Peter V, Tyukavina A, Vermote EF, Townshend JR (2018) Global land change from 1982 to 2016. Nature. https://doi.org/10.1038/s41586-0180411-9

Stephens SS, Wagner MR (2007) Forest plantations and biodiversity: a fresh perspective. J Forest 105(6):307-313. https://doi.org/10.1093/jof/105.6.307

Tal A, Gordon J (2010) Carbon cautious: israel's afforestation experience and approach to sequestration. Small-scale For 9(4):409-428. https://doi.org/10.1007/s11842-010-9125-z

Tak K, Chun Y, Wood PM (2007) The South Korean forest dilemma. Int for $\operatorname{Rev} 9(1): 548-557$. https://doi.org/10. 1505/ifor.9.1.548

Ternan JL, Williams AG, Elmes A, Fitzjohn C (1996) The effectiveness of bench-terracing and afforestation for erosion control on Raña sediments in central Spain. Land Degrad Dev 7(4):337-351

Thompson ID, Okabe K, Tylianakis JM, Kumar P, Brockerhoff EG, Schellhorn NA, Parrotta JA, Nasi R (2011) Forest biodiversity and the delivery of ecosystem goods and services: translating science into policy. Bioscience 61(12):972-981. https://doi.org/10.1525/bio.2011.61.12.7

Traugott. (1964). Media Terra. Zwischen Bosporus und Gibraltar.

Vadell E, Miguel S, Pemán J (2016) Large-scale reforestation and afforestation policy in Spain: a historical review of its underlying ecological, socioeconomic and political dynamics. Land Use Policy 55:37-48. https://doi.org/10. 1016/j.landusepol.2016.03.017

van Dijk AIJM, Keenan RJ (2007) Planted forests and water in perspective. For Ecol Manage 251(1-2):1-9. https://doi. org/10.1016/j.foreco.2007.06.010

Veldman JW, Overbeck GE, Negreiros D, Mahy G, Stradic SLE (2015) Where tree planting and forest expansion are bad for biodiversity and ecosystem services. Bioscience 65(10):1011-1018. https://doi.org/10.1093/biosci/biv118

Waring B, Neumann M, Prentice IC, Adams M, Smith P, Siegert $M$ (2020) Forests and decarbonization roles of natural and planted forests. Front for Glob Change. https://doi.org/10. 3389/ffgc. 2020.00058

Wilson SJ, Schelhas J, Grau R, Sloan S (2017) Forest ecosystem-service transitions: the ecological dimensions of the forest. Ecol Soc 22(4):38

Zanchi G, Thiel D, Green T, Lindner M (2007) Forest area change and afforestation in Europe: critical analysis of available data and the relevance for international environmental policies. European Forest Institute, Finland

Publisher's Note Springer Nature remains neutral with regard to jurisdictional claims in published maps and institutional affiliations. 